\title{
Classification-based repair techniques to correct tricuspid valve incompetence in Ebstein's anomaly and long-term functional outcome
}

\author{
R Hetzer, E Delmo Walter ${ }^{*}$ \\ From 23rd World Congress of the World Society of Cardio-Thoracic Surgeons \\ Split, Croatia. 12-15 September 2013
}

\section{Background}

We describe a repertoire of repair techniques according to types of Ebstein's anomaly to correct tricuspid valve (TV) incompetence, and report the long-term and functional outcome.

\section{Methods}

Sixty-eight (68) patients (mean age $26.9 \pm 7.3$ years) with Ebstein's anomaly (Types $\mathrm{A}=18, \mathrm{~A}=3, \mathrm{~B}=21, \mathrm{~B}-\mathrm{C}=2$, $\mathrm{C}=15, \mathrm{D}=9$ ) underwent correction of TV incompetence. The atrialized ventricle, the TV and subvalvar apparatus were inspected to analyze the precise morphology, and determine which leaflet was the most mobile. In all, the atrialized right ventricle (RV) is incorporated into the contractile RV by partial closure of the natural annulus using the most mobile leaflet for valve competence. Posterior annulorrhaphy was performed for Types A,B,C. The double orifice valve technique was employed mostly in types C and D.Sebening stitch, was applied in combination in most types. A combination of anterior and posterior annulorrhaphy was also performed for types A and $\mathrm{B}$. In 3 patients with type $\mathrm{C}$, additional bidirectional Glenn anastomosis was performed.

\section{Results}

Mean follow-up duration was $13.25 \pm 1.3$ (range 1-24.) years. Mean NYHA class improved from 3.4 to 1.3 $(\mathrm{p}<0.001)$. Severity of TV incompetence was reduced from 3.2 to $1.3(\mathrm{p}<0.001)$. Exercise tests demonstrated improvement in maximal oxygen uptake $(\mathrm{p}<0.02)$. Mean basal, middle and apical ventricular strain significantly improved to $25.7 \%(\mathrm{p}<0.011), 23.7 \%(\mathrm{p}<0.001)$ and

\footnotetext{
* Correspondence: delmo-walter@dhzb.de

Cardiothoracic Surgery, Deutsches Herzzentrum Berlin, Berlin, Germany
}

$19.36 \%(\mathrm{p}<0.05)$. Freedom from reoperation was $100 \%$ at 1 year and $92.9 \%$ at 5 and 20 years, respectively. Early and late mortality was $5.8 \%$ and $2.9 \%$ respectively. Overall survival rate was $94.2 \%$ and $91.26 \%$ at 30 days and 20 years, respectively.

\section{Conclusion}

The various repair techniques, which preserve the atrialized chamber, and employed individually according to morphology, provide satisfactory long-term ventricular function and functional outcome even in severe types of Ebstein's anomaly.

Published: 11 September 2013

doi:10.1186/1749-8090-8-S1-0137

Cite this article as: Hetzer and Delmo Walter: Classification-based repair techniques to correct tricuspid valve incompetence in Ebstein's

anomaly and long-term functional outcome. Journal of Cardiothoracic Surgery 2013 8(Suppl 1):0137.

Submit your next manuscript to BioMed Central and take full advantage of:

- Convenient online submission

- Thorough peer review

- No space constraints or color figure charges

- Immediate publication on acceptance

- Inclusion in PubMed, CAS, Scopus and Google Scholar

- Research which is freely available for redistribution

Submit your manuscript at www.biomedcentral.com/submit
C Biomed Central

\section{() Biomed Central}

